Research/Technical Note

\title{
Birth Preparedness and Complication Readiness Among Pokot Nomadic Pastoralists' Pregnant Women in East Pokot District, Midwest- Kenya
}

\author{
Kiptulon Evans Kasmai ${ }^{1}$, Onoja Mathew Akpa ${ }^{2}$, Oladapo Olayemi ${ }^{3}$ \\ ${ }^{1}$ Department of Obstetric and Gynaecology, Pan Africa University Institute for Life and Earth Sciences, University of Ibadan, Ibadan, Nigeria \\ ${ }^{2}$ Department of Epidemiology and Medical Statistics, University of Ibadan, Ibadan, Nigeria \\ ${ }^{3}$ Department of Obstetrics and Gynaecology, University of Ibadan, Ibadan, Nigeria
}

Email address:

evanskasmai@yahoo.com(K.E. Kasmai),onojamatthew@yahoo.co.uk(O.M. Akpa), oladapo.olayemi@yahoo.com(O. Olayemi)

\section{To cite this article:}

Kiptulon Evans Kasmai, Onoja Mathew Akpa, Oladapo Olayemi. Birth Preparedness and Complication Readiness Among Pokot Nomadic Pastoralists' Pregnant Women in East Pokot District, Midwest- Kenya. American Journal of Biomedical and Life Sciences.

Vol. 6, No. 1, 2018, pp. 17-23. doi: 10.11648/j.ajbls.20180601.13

Received: March 1, 2018; Accepted: March 14, 2018; Published: April 8, 2018

\begin{abstract}
Birth Preparedness and Complication Readiness (BPCR) is a strategy to promote the timely use of skilled maternal and neonatal care, especially during childbirth, based on the theory that preparing for childbirth and being ready for complications reduces delays in seeking health care and averts serious complications that women face during child birth. However, information on BPCR among Pokot nomadic pastoralists have not been well documented in literatures. The purpose of this research was to determine factors affecting BPCR among Pokot nomadic pastoralists' pregnant women living in East Pokot District of Kenya. A cross-sectional facility based study was conducted among 275 Pokot pregnant women, above 18 years of age who were on their second and third trimesters and attending various Antenatal Clinics (ANCs) in East Pokot district. This was response rate of $90.1 \%$. A multi-stage sampling technique was used and data was collected from those who met the inclusion criteria between August-October, 2017, using a pretested researcher administered questionnaire. The data collected was analyzed using (SPSS) version 21. Chi-square was used to test the hypothesis. A p-value of $<0.05$ was considered significant. The results showed that practice of BPCR was low (28\%) among the respondents. Being educated $(\mathrm{OR}=18, \mathrm{CI}=3.83-85.16)$ and having high household income $(\mathrm{OR}=2.53, \mathrm{CI}=1.37-4.66)$ increased practice of $\mathrm{BPC} \mathrm{R}$. Ethnic affiliation to Pokot $(\mathrm{OR}=4.85, \mathrm{CI}=1.38-17.07)$, practicing African Traditional Religion $(\mathrm{OR}=2.48, \mathrm{CI}=1.44-4.26)$, practicing pastoralism $(\mathrm{OR}=2, \mathrm{CI}=1.17-3.42)$ were found to significantly reduce the level of BPCR. In conclusion, birth preparedness and complication readiness was low among Pokot nomadic pastoralist's pregnant women. There is a need for more BPCR awareness programmes targeting pastoralists' women and other vulnerable groups in the region.
\end{abstract}

Keywords: Birth Preparedness and Complication Readiness, Nomadic Pokot Pastoralist, Maternal Mortality, East Pokot District, Obstetric Danger Signs

\section{Introduction}

Maternal mortality has continued to be the greatest public health problem in Sub-Saharan Africa [1]. Globally, Sub-Sahara Africa (SSA), Kenya included, account for $99 \%$ of world's maternal deaths [1]. Maternal mortality in Kenya remains unacceptably high despite several efforts put in place by government and other stakeholders. In 2008 and 2014 for example, the country's Maternal Mortality Ratio (MMR) was 362 deaths per 100,000 live births and 488/100,000 respectively [2]. These statistics indicate relatively a slow progress in reduction of MMR in the five year period.

Pastoralists' regions in the country have been shown to carry the highest burden of maternal deaths with top five counties having high MMR being occupied by pastoralist communities. These include Mandera, Wajir, Turkana, 
Marsabit and Isiolo. Fifteen out of 47 counties account for 98.7\% MMR with West Pokot and East Pokot regions being among these 15 areas [3].

Birth preparedness and complication readiness (BPCR) is a safe motherhood strategy whose main objective is to promote timely use of skilled maternal and neonatal care during childbirth and obstetric emergencies by reducing delays in deciding to seek health care by pregnant women at first, second and third stages of delays in health seeking [4]. Planning entails the woman identifying a reliable place of delivery, skilled birth attendant, decision maker during emergency, saving emergency funds, knowing the expected day of delivery, screening for HIV/AIDS, buying items required for birth and arranging in advance for emergency transport $[4,5]$. BPCR is a crucial component in reduction of maternal and neonatal deaths especially in pastoral and remote regions of the world. In 2006, World Health Organization (WHO) recommended BPCR as a safe motherhood strategy and advised that, women should have a written BPCR plan [6].

Knowledge of factors affecting BPCR among pastoralists' communities is central to designing the right programs to reduce maternal and child mortality among this vulnerable group of people. Majority of nomadic pastoralists live in harsh and uncertain environments where they face water shortages, lack of pasture for their large herds, animal diseases, drought and famine as well as cattle rustling [7]. Constant migration thus is the only tool of evading myriads of problems facing them [8,9]. This has made it difficult for governments to provide quality health services to pastoralists. The present study was designed to assess factors affecting BPCR among Pokot nomadic pastoralists, pregnant women in East Pokot District in Kenya, determining their level of BPCR as well as the association between socio demographic, obstetric and socio economic factors on of BPCR.

\section{Methods}

\subsection{Study Design and Study Location}

This was a cross-sectional facility based study among 275 Pokot nomadic pastoralists' pregnant women, above 18 years of age who were on their second and third trimesters and attending various government, faith based and mobile antenatal clinics in East Pokot District, Baringo County of Kenya. The district is sub-divided into six divisions/wards and covers an area of 4516.8 square kilometers. These wards are Tirioko, Koloa, Ribkwo, Silale, Loyamotok, Tangulbei/Korossi and Churo/Amaya wards. The whole district is mainly arid and semi-arid and supports little or no agricultural activity. It is predominantly and almost purely inhabited by the Pokot pastoralist community and the major economic activity is nomadic pastoralism [10]. Pokot culture is deeply rooted in pastoralism and their attitude and perception of cattle can only be compared to that of gold or money in the modern society $[11,17]$. The cow, also known as (Tany or Chemang'any) in Pokot is the greatest valued animal on earth.

According to the 2009 Kenya population and housing census [15], East Pokot district had a population of 133,189 people. 69,889 of the population were men while 63,300 were women. A total of 25,619 of female population were at reproductive ages of 15-49 years.

\subsection{Sampling Technique}

Multistage sampling technique was used. Firstly, a purposive sampling of six wards: Kolowa, Silale, Loyamorok, Tangulbei, Tirioko and Ripko wards were done. Churo ward was left out since community here was more settled and practiced farming and less pastoralism. Through stratified sampling, the community in each ward was grouped into locations, sub-locations and villages based on where the pastoralists live and the number of questionnaires to be administered per ward was calculated. Lastly, in the wards, hospitals offering antenatal clinics were identified. In the clinics, a convenience sampling method was used to select pregnant women who were 18 years of age or older and were either on their second or third trimesters for data collection purposes.

\subsection{Data Collection Process}

The study utilized standardized BPCR questions from Johns Hopkins Program for International Education in Gynecology and Obstetrics tool [4] and also developed more questions. Data was collected through a semi-structured pre-tested researcher administered questionnaire between August and October, 2017. The questionnaire was translated into Pokot local language for easier understanding by the local community.

\subsection{Measurement}

A total of 5 dependent variables such as: identification of skilled birth attendant, reliable means of transport during emergence, saving money for emergency use, saving food stuffs and identification of blood donor were used as variables to measure BPCR. Anybody who responded "YES" to any of the above variables was scored $1 / 5$ marks and 0 mark when the responds was "NO". Furthermore, BPCR was categorized to Poor, Moderate and High knowledge by calculating percentages of all the variable scores and converting to percentiles (Poor if score $\leq 25^{\text {th }}$ percentile, Moderate if $25^{\text {th }}$ percentile $<$ score $\leq 75^{\text {th }}$ percentile and Good if score $>75^{\text {th }}$ percentile).

\subsection{Data Management and Analysis}

The collected raw data was daily checked manually for completeness after collection. It was then categorized, coded and entered into Statistical Package for the Social Science (SPSS) version 21 for analysis. Chi-square was used to test the association between categorical variables and binary logistic regression was used to determine predictors of BPCR. A p-value of $<0.05$ was considered significant. The data was presented using frequencies, percentage and was presented in the form of tables, graphs and pie charts. 


\subsection{Ethical Approval}

The study protocol for this research was obtained from University College Hospital, University of Ibadan and Moi University College of Health Sciences \& Moi Teaching and Referral Hospital Institutional Research and Ethics Committees (IREC). Tiaty Sub-county ministry of health also gave permission for the research.

\section{Results}

\subsection{Socio Demographic Characteristics of the Respondents}

The ages of the respondents ranged between 18 and 44 years. Majority $(n=73)$ aged between 25-29 years. The vast majority of the respondents $96 \%(n=264)$ were from Pokot ethnic community while $4 \%(n=11)$ were from other Kenyan tribes. More than half of the women (62.9\%) practiced African traditional religion while $36.4 \%$ and $0.7 \%$ practiced both Christianity and Islam respectively. Regarding marital status, 95.6\% $(n=263)$ were married. Majority $82.2 \%(n=226)$ never went to school thus could not read and write [table 1].

Table 1. Socio demographic characteristics of the respondents.

\begin{tabular}{|c|c|c|}
\hline Variable & Frequency $(n=275)$ & Percentages (\%) \\
\hline \multicolumn{3}{|l|}{ Age } \\
\hline $15-19$ & 25 & 9.1 \\
\hline $20-24$ & 63 & 22.9 \\
\hline $25-29$ & 73 & 26.5 \\
\hline $30-34$ & 63 & 22.9 \\
\hline $35-39$ & 36 & 13.1 \\
\hline $40-44$ & 12 & 4.4 \\
\hline Don't know & 3 & 1.1 \\
\hline \multicolumn{3}{|l|}{ Ethnicity } \\
\hline Pokot & 264 & 96 \\
\hline Other Kenyan tribes & 11 & 4 \\
\hline \multicolumn{3}{|l|}{ Religion } \\
\hline Muslim & 2 & 0.7 \\
\hline Christian & 97 & 36.4 \\
\hline African traditional religion & 173 & 62.9 \\
\hline \multicolumn{3}{|l|}{ Marital Status } \\
\hline Single & 9 & 3.3 \\
\hline Married & 263 & 95.6 \\
\hline Widowed & 1 & 0.4 \\
\hline Separated & 2 & 0.7 \\
\hline \multicolumn{3}{|l|}{ Age at first marriage in years } \\
\hline Approximately 18 and below & 211 & 76.7 \\
\hline $19-24$ & 56 & 20.4 \\
\hline 25 and above & 4 & 1.5 \\
\hline Not married & 1 & 0.4 \\
\hline Don't know & 3 & 1.1 \\
\hline \multicolumn{3}{|l|}{ Educational Level } \\
\hline Some Primary & 26 & 9.8 \\
\hline Completed Primary & 10 & 3.6 \\
\hline Secondary & 6 & 2.2 \\
\hline College/University & 6 & 2.2 \\
\hline Never went to school & 226 & 82.2 \\
\hline
\end{tabular}

\subsection{Socio Economic Characteristics of the Respondents}

Majority of the respondents $91.3 \%(n=251)$ had no work and mainly played the housework roles. Livestock was owned by big number of the respondents' families. On monthly income, most of the women reported that their families had no monthly income $(n=114)$ while $37.8 \%$ of the respondents reported that their monthly income ranged between 50.1 to 150 US dollars (USD). Concerning movement from their residents in the past two years, pastoralism was found to be practiced by $51.3 \%(n=141)$ of the respondents [table 2].

Table 2. Socio economic characteristics of the respondents.

\begin{tabular}{lll}
\hline Variable & $\begin{array}{l}\text { Frequency } \\
(\mathbf{n = 2 7 5 )}\end{array}$ & $\begin{array}{l}\text { Percentages } \\
(\%)\end{array}$ \\
\hline $\begin{array}{l}\text { Respondents other work other than } \\
\text { Housework }\end{array}$ & \\
Yes & 24 & 8.7 \\
No & 251 & 91.3 \\
Livestock Ownership & & \\
Yes & 260 & 94.5 \\
No & 15 & 5.5 \\
Household's monthly Income & & \\
\$ 10-50 & 51 & 18.5 \\
\$ 50.01-150 & 104 & 37.8 \\
\$ 150.01-300 & 6 & 2.2 \\
None & 114 & 41.5 \\
Pastoralism Nature & & \\
Moved in the last two years & 141 & 51.3 \\
Didn't move in the last two years & 134 & 48.7 \\
\hline
\end{tabular}

\subsection{Obstetric Characteristics of the Respondents}

The research was done on pregnant women who were on their second trimester $(\mathrm{n}=154,56 \%)$ and third trimester $(\mathrm{n}=121,44 \%)$. Majority $86.9 \%$ of the respondents knew only their month of delivery. A big number of the women $81.7 \%$ reported to have attended ANC in their previous pregnancy. Majority $82.3 \%$ delivered their previous babies at home with unskilled birth attendants [table 3].

Table 3. Obstetric characteristics of the respondents

\begin{tabular}{|c|c|c|}
\hline Variable & $\begin{array}{l}\text { Frequency } \\
(n=275)\end{array}$ & $\begin{array}{l}\text { Percentages } \\
(\%)\end{array}$ \\
\hline \multicolumn{3}{|l|}{ Gestation period } \\
\hline Second trimester & 154 & 56 \\
\hline Third trimester & 121 & 44 \\
\hline \multicolumn{3}{|l|}{ Expected date of delivery } \\
\hline Know date of delivery & 9 & 3.3 \\
\hline Knows only month of delivery & 239 & 86.9 \\
\hline Don't know date or month & 27 & 9.8 \\
\hline \multicolumn{3}{|l|}{ Was it the participants first pregnancy } \\
\hline Yes & 140 & 14.5 \\
\hline No & 235 & 85.5 \\
\hline \multicolumn{3}{|l|}{$\begin{array}{l}\text { ANC attendance in previous } \\
\text { pregnancy }\end{array}$} \\
\hline Yes & 192 & 81.7 \\
\hline No & 42 & 18.3 \\
\hline \multicolumn{3}{|l|}{ Number of present ANCs attendance } \\
\hline First & 145 & 52.7 \\
\hline Second & 56 & 20.4 \\
\hline Third & 46 & 16.7 \\
\hline Fourth & 25 & 9.1 \\
\hline More than 4 times & 3 & 1.1 \\
\hline Previous place of delivery & & \\
\hline $\begin{array}{l}\text { In health facility with skilled birth } \\
\text { attendant }\end{array}$ & 40 & 17.7 \\
\hline $\begin{array}{l}\text { At home with traditional birth } \\
\text { attendant }\end{array}$ & 195 & 82.3 \\
\hline
\end{tabular}




\begin{tabular}{lll}
\hline Variable & $\begin{array}{l}\text { Frequency } \\
(\mathbf{n = 2 7 5 )}\end{array}$ & $\begin{array}{l}\text { Percentages } \\
(\mathbf{\%})\end{array}$ \\
\hline $\begin{array}{l}\text { Complications in the previous } \\
\text { delivery }\end{array}$ & & \\
Yes & 88 & 37.1 \\
No & 149 & 62.9 \\
$\begin{array}{l}\text { Plan on where to delivery their } \\
\text { current pregnancy }\end{array}$ & \\
$\begin{array}{l}\text { In health facility with skilled birth } \\
\text { attendant }\end{array}$ & 70 & \\
$\begin{array}{l}\text { At home with traditional birth } \\
\text { attendant }\end{array}$ & 93 & 25.5 \\
Don't know & 112 & 33.8 \\
\hline
\end{tabular}

\subsection{Level of Birth Preparedness and Complications Readiness of the Respondents}

Five key variables were used to determine the levels of BPCR from the respondents. The research found that, more than three quarter of the women had not put in place any of the five specific factors of BPCR [Table 4]. On categorization of BPCR into poor, moderate and high using percentiles, it was found that $72 \% \quad(n=198)$ of the respondents were poorly prepared, $28 \%(n=28)$ were highly prepared and no respondent was in the moderately prepared category [Figure 1).

Table 4. Level of Birth Preparedness and complications readiness of the respondents.

\begin{tabular}{|c|c|c|c|c|}
\hline Variable & Yes & & No & \\
\hline & Frequency & Percentage (\%) & Frequency & Percentage $(\%)$ \\
\hline Have you identified a reliable mode of transport? & 15 & 5.5 & 260 & 94.5 \\
\hline Have you saved money? & 33 & 12.0 & 242 & 88.0 \\
\hline Have you Identified blood donor? & 6 & 2.2 & 269 & 97.8 \\
\hline Have you Identified skilled birth attendant? & 46 & 16.7 & 229 & 83.3 \\
\hline Saved foodstuffs (grains)? & 23 & 8.4 & 252 & 91.6 \\
\hline
\end{tabular}

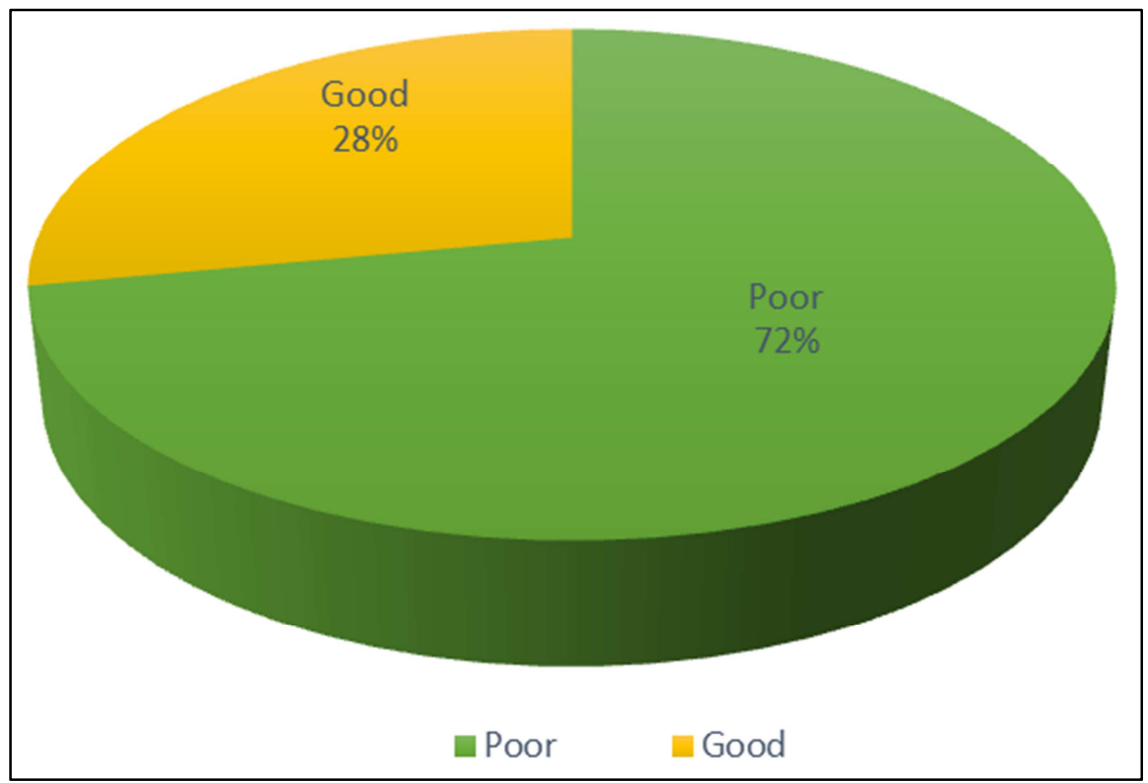

Figure 1. Percentile categorization of BPCR to 'Poor', 'Moderate' and 'Good'.

\subsection{Association of Socio-Demographic, Socio-Economic and Obstetric Factors with BPCR}

The research findings showed that ethnicity $\left(\mathrm{X}^{2}=7.23, \mathrm{P}=\right.$ $0.007)$, religion $\left(\mathrm{X}^{2}=11.08, \mathrm{P}=0.001\right)$, level of education
$\left(\mathrm{X}^{2}=30.53, \mathrm{P}<0.001\right)$, expected dates of delivery $\left(\mathrm{X}^{2}=4.24, \mathrm{P}=\right.$ $0.04)$, time to the nearest health facility $\left(\mathrm{X}^{2}=17.1, \mathrm{P}=0.002\right)$, household income $\left(\mathrm{X}^{2}=9.29, \mathrm{P}=0.01\right)$ and pastoralism $\left(\mathrm{X}^{2}=6.49, \mathrm{P}=0.01\right)$ all had significant association with BPCR.

Table 5. Chi square analysis showing association of socio-demographic, socio-economic and obstetric factors with BPCR.

\begin{tabular}{|c|c|c|c|c|}
\hline Variables & Poor BPCR (\%) & Good BPCR (\%) & $X^{2}$ & P value \\
\hline \multicolumn{5}{|l|}{ Ethnicity } \\
\hline Pokot & 194(98.0) & $70(90.9)$ & \multirow[t]{2}{*}{7.23} & \multirow[t]{2}{*}{0.007} \\
\hline Others & $4(2.0)$ & $7(9.1)$ & & \\
\hline \multicolumn{5}{|l|}{ Religion } \\
\hline Christian & $58(29.3)$ & $39(50.6)$ & \multirow[t]{2}{*}{11.08} & \multirow[t]{2}{*}{0.001} \\
\hline African traditional religion/ others & $140(70.7)$ & $38(49.4)$ & & \\
\hline Some Primary/ Completed Primary & $19(9.6)$ & $18(23.4)$ & \multirow[t]{2}{*}{30.53} & \multirow[t]{2}{*}{$<0.001$} \\
\hline Secondary/College/ University & $2(1.0)$ & $10(13.0)$ & & \\
\hline
\end{tabular}




\begin{tabular}{|c|c|c|c|c|}
\hline Variables & Poor BPCR (\%) & Good BPCR (\%) & $X^{2}$ & P value \\
\hline Never went to school & $177(89.4)$ & $49(63.6)$ & & \\
\hline \multicolumn{5}{|l|}{ Expected date of delivery } \\
\hline Know date or month of delivery & 174(87.9) & $74(96.1)$ & 4.24 & 0.04 \\
\hline Don't know date or month & $24(12.1)$ & $3(3.9)$ & & \\
\hline \multicolumn{5}{|l|}{ Time to the nearest health facility } \\
\hline Less than half an hour & $9(4.5)$ & $15(19.5)$ & 17.1 & 0.002 \\
\hline Less than 1 hour & $25(12.6)$ & $7(9.1)$ & & \\
\hline Less than 2 hours & $33(16.7)$ & $15(19.5)$ & & \\
\hline More than 2 hours & $130(65.7)$ & $40(51.9)$ & & \\
\hline Don't know & $1(0.5)$ & $0(0.0)$ & & \\
\hline \multicolumn{5}{|l|}{ Household's monthly Income } \\
\hline$\$ 10-50$ & $35(17.7)$ & $16(20.8)$ & 9.29 & 0.01 \\
\hline$\$ 50.01$ and above & $70(35.4)$ & $40(51.9)$ & & \\
\hline None & $93(47.0)$ & $21(27.3)$ & & \\
\hline \multicolumn{5}{|l|}{ Pastoralism Nature } \\
\hline Moved in the last two years & $111(56.1)$ & $30(39.0)$ & 6.49 & 0.01 \\
\hline Didn't move in the last two years & $87(43.9)$ & $47(61.0)$ & & \\
\hline
\end{tabular}

\subsection{Binary Logistic Regression of the Association Between Socio Demographic, Socio Economic and Obstetric Factors on BPCR}

Binary logistic regression was done on the factors which were significant on chi-square to further determine the independent predictors of BPCR. The findings found that ethnicity was significantly associated with BPCR. Other Kenyan tribes living in the region were found to be about 5 times more likely to be prepared for birth and complications compared to those from Pokot tribe $(\mathrm{OR}=4.85, \mathrm{p}=0.01)$. Respondents who were Christians were 2 times more likely to be prepare for birth and complications than those who practiced African Traditional Religion and other religions (OR $=2.48, \mathrm{p}=0.001)$. Age at first marriage was another significant factor and those who got married at age above 25 years were about 5 times more likely to be prepared than those who got married at the ages of 18 years or below $(\mathrm{OR}=4.73, \mathrm{p}$ $=0.04$ ). Furthermore, those who had some primary education or had completed primary education were 3 times more likely to be prepared for birth and complications compared to those who never went to school $(\mathrm{OR}=3.42, \mathrm{p}=0.001)$ while women who had secondary, college or university education were massively 18 times more likely to be prepared than those who never went to school $(\mathrm{OR}=18.1, \mathrm{p}=<0.001)$.

On the time to get to the nearest health facility, those whose time to the nearest health facility was one hour, 2 hours and more than two hours ( $\mathrm{OR}=0.17,0.27$ and 0.19 respectively) were less likely to be prepared for birth and complications compared than those who take less than half an hour to the nearest facility. In addition, those who earned $\$ 50.01$ and above per month were about 3 times more likely to be prepared for birth compared to those who say they did not have any monthly income $(\mathrm{OR}=2.53, \mathrm{p}=0.003)$.

On the pastoralism nature of the respondents, it was found that, those who do not move from place to place were 2 times more likely to be prepared for birth compared and complications than those who practice pastoralism $(\mathrm{OR}=2, \mathrm{p}$ $=0.01)$.
Table 6. Binary logistic regression of the association between socio demographic, socio economic and obstetric factors on BPCR.

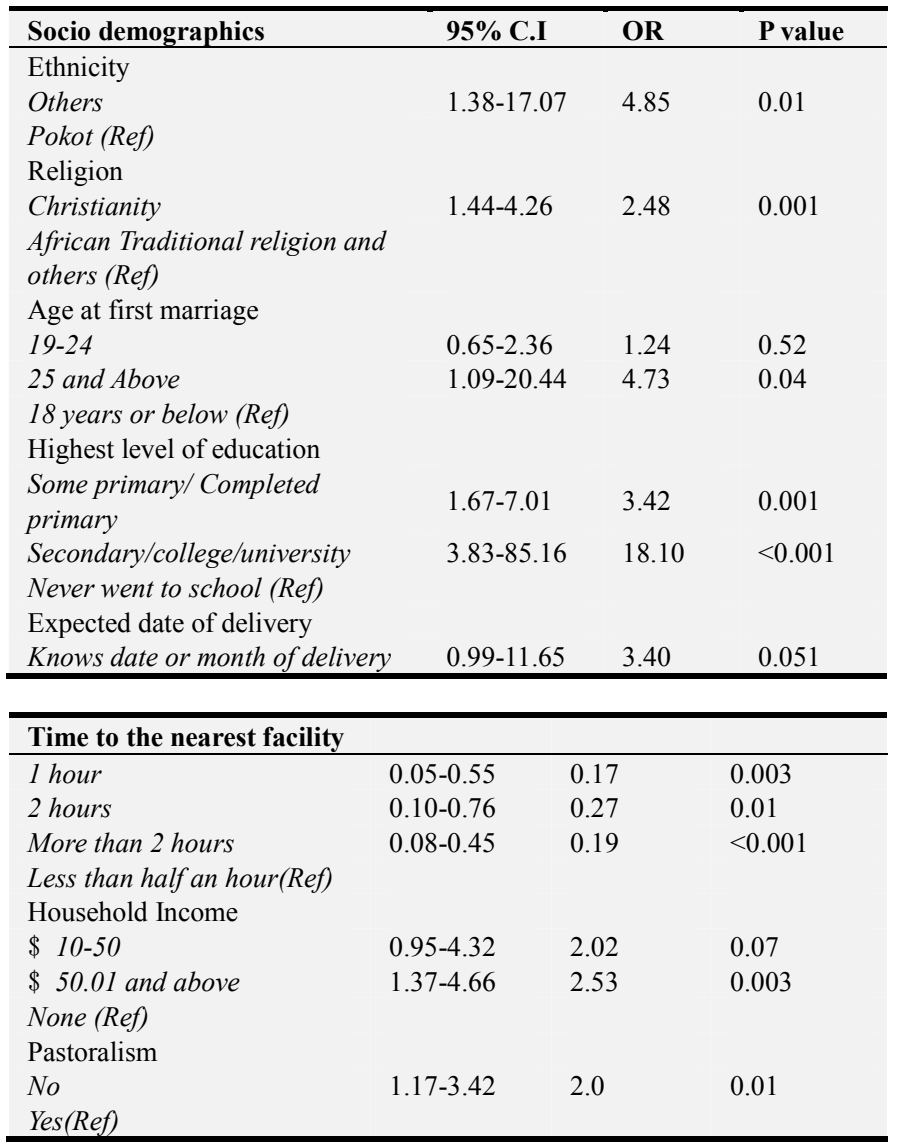

Ref $=$ Reference category $*$ significant at $\mathrm{p}<0.05$

\section{Discussion}

This study revealed that a larger populace $72 \%$ of Pokot nomadic pastoralists' pregnant women were poorly prepared for birth and its complications while only $28 \%$ were well prepared. Extremely low number of respondents had put in 
place the five fundamental steps of BPCR which includes identification of skilled birth attendant, reliable means of transport during emergence, blood donor, saving money for emergency use or saving food stuffs. This could mainly be attributed to lack of enough health facilities, inadequate skilled health professionals, poor infrastructure, constant pastoralist movement and harmful traditional practices and beliefs among the Pokot community. The area is a hardship region, a semi-arid land always hit by insecurity due to continued cattle raids between the Pokot, Turkana, Samburu, Ilchamus, Marakwet and Tugen. Pastoralism figured prominently as a factor displacing women away from health facilities and skilled birth attendants something that other researchers had previously raised [16, 18].

This findings is similar with other research results reported among women attending Bowen University Hospital, South West Nigeria where BPCR was 40.3\% [5] and a research done among pregnant women in Jimma Zone of Ethiopia where only 23.3\% BPCR was reported [12] although the two researches were not done among pastoralists. It however contradicted researches conducted in Kenya by Mutiso et al. which found that pregnant women attending Kenyatta National Hospital were highly prepared for birth and its complications [13]. Similarly, it contradicted a research done among pregnant women attending clinics in Bureti Sub-county facilities in Kenya where the respondents were found to be well prepared for birth and complications [14].

The research further found that ethnicity, religion, age at first marriage, knowing expected dates of delivery, time to the nearest health facility, household income and pastoralism we key predictors to BPCR but education level of the respondents was the strongest predictor and women who had secondary, college or university education was far much 18 times more likely to be prepared compared to those who never went to school. Contrarily $82 \%$ of the women never went to school and this could be another major reason for poor BPCR. Education empowers women economically, socially and on BPCR decision making. However, this is less practical among pastoralists as their children have the highest school dropout rates because they have to accompany their parents each time they move.

In our study, a large portion of the respondents had attended ANCs in their previous pregnancy. High ANCs attendance in many literatures had been found to be a strong catalysts to high knowledge and practice of BPCR. However, this was largely contradicted in this research as many of the respondents either planned to deliver at home with traditional birth attendants or did not even have a plan at all of where to deliver. These results therefore put into doubt the reliability of health education services the pastoralists' women get from ANCs in relation to BPCR.

\section{Conclusion}

This research findings showed that the proportion of Pokot pastoralist's pregnant women who were well prepared for birth and complication was low. This is a negative sign towards reducing maternal mortality and morbidity. When emergencies occur in hard to reach and adversely remote areas, they most probably always end in deaths. Every pregnancy is a risky pregnancy. There is the need for more BPCR awareness programmes targeting pastoralists' women and other vulnerable groups in the region in order to successfully reduce maternal mortality.

\section{Recommendation}

This research recommended that the national and county governments should continue mobile clinics in the area and BPCR should be emphasized as it is one of important ways of reducing maternal mortality. Accessibility to formal education in the region especially girl child and adult education should be made possible. The region's infrastructure should be improved.

The government through free maternity should not only place emphasis on cost of delivery but also on access and availability of services especially in pastoral communities.

\section{List of Abbreviations}

AIDS-Acquired immunodeficiency syndrome, ANCsAntenatal Clinics, BPCR-Birth Preparedness and Complication Readiness, C.I- Confidence Interval, HIV-Human Immunodeficiency virus, IREC- Institutional Research and Ethics Committee, MMR-Maternal Mortality Ratio, SSA- Sub-Sahara Africa, OR- Odd Ratio, SPSSStatistical Package for the Social Sciences, USD- United States Dollar, WHO-World Health Organization.

\section{Conflict of Interest}

The authors to this research declare that they have no conflict of interest relevant to this study.

\section{References}

[1] WHO (2015). Guide for measuring maternal mortality PRB, (December), 1-6. Retrieved from http://r4d.dfid.gov.uk/PDF/Outputs/Immpact/ImmpactMeasur ementFactSheet.pdf

[2] Kenya Demographic Health Survey(2014).

[3] UNFPA(2014).

Kenya.unfpa.org/en/news/un-bestows-honours-kenyas-first-la dy Newsletter, (September), 1-16.

[4] JHPIEGO.(2004). Birth preparednessand complicationreadiness, $1-338$. https://doi.org/10.5588/pha.13.0025

[5] Ajibola, I., Deji, S. A., Olatayo, Ayodele Aremu, ;, Bojuwoye, O. M., \& Akinyemi, D. O. (2015). Birth Preparedness and Complication Readiness among Women Attending Antenatal Clinics in Ogbomoso, South-west Nigeria. International Journal for MCH and AIDS, 4(1), 47-56. 
[6] WHO. (2006). Birth and emergency preparedness in antenatal care. Intergrated Management of Pregnancy and Childbirth. Retrieved from

http://scholar.google.com/scholar?hl=en\&btnG=Search\&q $=$ intitle:Birth+and + emergency + preparedness + in + antenatal + care\#3

[7] Kaye-Zwiebel, E., \& King, E. (2014). Kenyan pastoralist societies in transition: Varying perceptions of the value of ecosystem services. Ecology and Society, 19(3). https://doi.org/10.5751/ES-06753-190317

[8] Homewood, K. (2006). As Pastoralists Settle: Social, Health and Economic Consequences of Pastoral Sedentarization in Marsabit District, Kenya. Human Ecology, 34(2), 297-299. https://doi.org/10.1007/s10745-006-9018-0

[9] Kiprotich Chebunet, P., \& Cherono Laboso Abonyo, J. (2013). Cultural Beliefs as a Source of Ethnic Conflicts: A Study of the Turkana and Pokot Pastoralists of Kenya. Journal of Global Peace and Conflict, 1(11), 1-14.

[10] Ochieng, J., Protection, C., Manager, P., Lilah, J., \& Officer, P. (2010). East pokot District, Kenya humanitarian assessment 14 th - 16 th january 2010 Assessment team :, (January).

[11] Mutsotso, B. M., \& Kimaiyo, David, Gaicuki, P. (2014). the Centrality of Cattle in the Social Organization of the East Pokot Pastoralists of North Western Kenya. European Scientific Journal, 10(8), 491-507.

[12] Debelew, G. T., Afework, F., \& Yalew, A. W. (2014). Factors affecting birth preparedness and complication readiness in Jimma Zone, Southwest Ethiopia: A multilevel analysis. Pan African Medical Journal, 19, 1-14. https://doi.org/10.11604/pamj.2014.19.272.4244.

[13] Mutiso, S. M., Qureshi, Z., \& Kinuthia, J. (2008). Birth preparedness among antenatal clients. East African Medical Journal, 85(6), 275-283.

https://doi.org/10.4314/eamj.v85i6.9625.

[14] Omari, P. K., Afrane, Y. A., \& Ouma, P. (2016). Birth Preparedness and Complication Readiness among Women Attending Antenatal Care Clinic in Health Facilities within Bureti Sub County of Kericho County, 6(4), 123128.https://doi.org/10.5923/j.ajmms.20160604.01

[15] KNBS. (2010). The 2009 Kenya Population and Housing Census - Population Distribution by Age, Sex and Administrative Units., IC, 546.

[16] Schrepfer, N., \& Caterina, M. (2014). On the margin: Kenya's pastoralists From displacement to solutions, a conceptual study on the internal displacement of pastoralists, (3), 1-40.

Retrieved from http://www.internal-displacement.org/assets/publications/2014 /201403-af-kenya-on-the-margin-en.pdf

[17] Huho, J. M. (2012). Conflict Resolution Among Pastoral Communities in West Pokot County, Kenya: a Missing Link. Academic Research International, 3(3), 2223-9553. Retrieved from www.savap.org.pk

[18] Rodriguez, L., \& International, T. (2008). A Global Perspective on the total economic value of pastoralism: Global synthesis report based on six country valuations, 1-24. 